\title{
Endoscopic perforation rates at a Canadian university teaching hospital
}

\author{
Tarun Misra MD, Eoin Lalor MB FRCPC, Richard N Fedorak MD FRCPC
}

T Misra, E Lalor, RN Fedorak. Endoscopic perforation rates at a Canadian university teaching hospital. Can J Gastroenterol 2004;18(4):221-226.

BACKGROUND: Despite advances in training, operative techniques and endoscopic technology, upper and lower endoscopic procedures continue to have potential for intestinal perforation. Perforation rates provided to patients at the time of consent have frequently been derived from historical cohorts and survey datasets. OBJECTIVE: This study examined the perforation rates of upper and lower endoscopic procedures at a major Canadian tertiary care centre.

METHODS: Inpatient and outpatient gastroscopies and colonoscopies performed during a three year period were evaluated. Endoscopies with perforations occurring within 14 days of procedure were retrospectively isolated using the International Classification of Diseases - 9th Revision code descriptions, then retrieved and hand searched to confirm a procedure-related perforation. Data were extracted to identify risk factors and patient outcomes.

RESULTS: A total of 21,217 endoscopies (13,792 gastroscopies and 7425 colonoscopies) were reviewed. Of these, 359 were identified, isolated and hand searched for confirmation of a perforation event. Eighteen were found to have an endoscopy-associated perforation. Ten perforations occurred with colonoscopy $(0.13 \%)$ (incidence, $1.3 / 1000$ procedures), resulting in one death $(0.013 \%)$ (incidence, $0.13 / 1000$ procedures). Eight perforations occurred with gastroscopy $(0.06 \%)$ (incidence, $0.6 / 1000$ procedures), resulting in zero mortality. Of colonoscopy procedures the rate of perforation with diagnostic colonoscopy was $0.13 \%$ (incidence, $1.3 / 1000$ procedures) and with therapeutic colonoscopy was $0.14 \%$ (incidence, $1.4 / 1000$ procedures). Of gastroscopy procedures the rate with therapeutic gastroscopy was $0.15 \%$ (incidence, $1.5 / 1000$ procedures). No perforations occurred with diagnostic gastroscopy.

CONCLUSION: Gastroscopy and colonoscopy procedures, especially those with therapeutic maneuvers, continue to carry morbidity and mortality risks associated with perforation.

Key Words: Colonoscopy; Complication; Endoscopy; Gastroscopy; Morbidity; Mortality; Perforation

\section{Taux de perforation liés aux endoscopies dans un centre hospitalier universitaire au Canada}

CONTEXTE : Malgré les progrès réalisés dans la formation, les techniques d'utilisation et la technologie, les endoscopies digestives hautes et basses comportent toujours des risques de perforation de l'intestin. Les taux de perforation présentés aux patients au moment du consentement proviennent souvent de cohortes historiques et de données d'enquêtes. OBJECTIF : La présente étude a porté sur les taux de perforation liés aux endoscopies hautes et basses, effectuées dans un grand centre de soins tertiaires au Canada.

MÉTHODE : Nous avons évalué les gastroscopies et les coloscopies pratiquées sur des patients externes et des patients hospitalisés sur une période de trois ans. Les endoscopies suivies d'une perforation notée dans les 14 jours après l'intervention ont été repérées de façon rétrospective à l'aide des codes de la Classification internationale des maladies, $9^{\mathrm{e}}$ édition, puis récupérées et soumises à une recherche manuelle pour confirmer le lien entre la perforation et l'intervention. L'extraction des données avait pour but de relever les facteurs de risque et les résultats de l'examen.

RÉSULTATS : Au total, 21217 endoscopies (13 792 gastroscopies et 7425 coloscopies) ont été passées en revue. Sur ce nombre, 359 ont fait l'objet d'une recherche manuelle en vue d'une confirmation de la perforation, et 18 dossiers se sont avérés des cas de perforation liés à l'endoscopie. Dix perforations ont été associées à la coloscopie $(0,13 \%)$ (incidence : $1,3 / 1000$ interventions), dont une s'est soldée par la mort du patient $(0,013 \%)$ (incidence : 0,13/1000 interventions). De son côté, la gastroscopie a été associée à huit perforations (0,06\%) (incidence : 0,6/1000 interventions), et aucune n'a entrâné la mort du patient. En ce qui concerne les coloscopies, le taux de perforation associé aux interventions diagnostiques était de 0,13\% (incidence : 1,3/1000 interventions) et celui associé aux interventions thérapeutiques, de 0,14\% (incidence : 1,4/1000 interventions). Quant aux gastroscopies, le taux de perforation associé aux interventions thérapeutiques était de 0,15\% (incidence : $1,5 / 1000$ interventions). Pour ce qui est des gastroscopies à visée diagnostique, elles n'ont donné lieu à aucune perforation.

CONCLUSION : Les gastroscopies et les coloscopies, notamment à visée thérapeutique, comportent toujours des risques de morbidité et de mortalité associés aux perforations.

Table 1 outlines the published reports of colonoscopyassociated perforation rates during the last 30 years. The reported rate of colonic perforation ranges from a high of $1.3 \%$ to a low of $0 \%(1-18)$. Studies with the highest reported rate of perforations are those conducted at a time when colonoscopy was a relatively new procedure, and may not be representative of current colonoscopic practice. In contrast, retrospective and prospective studies conducted since 1996 have reported lower rates of perforation, with diagnostic colonoscopic perforation important diagnostic and therapeutic tool that has revolutionized the management of patients with gastrointestinal dis eases. Although flexible upper and lower endoscopy, with current endoscopic equipment and appropriate training is considered a safe procedure, like all other procedures in medicine, there remains identifiable potential for adverse events and complications. One of the most serious of these complications is intestinal perforation.

Division of Gastroenterology, University of Alberta, Edmonton, Alberta

Correspondence: Dr Richard N Fedorak, Division of Gastroenterology, University of Alberta, College Plaza, Suite 205, 8215 - 112th Street,

Edmonton, Alberta T6G 2C1. Telephone 780-492-6941, fax 780-492-8211, e-mail Richard.fedorak@ualberta.ca

Received for publication June 25, 2003. Accepted February 12, 2004. 
TABLE 1

Published reports of colonoscopy-associated perforation rates during the last $\mathbf{3 0}$ years

\begin{tabular}{|c|c|c|c|c|}
\hline $\begin{array}{l}\text { Author } \\
\text { year (ref) }\end{array}$ & $\begin{array}{c}\text { Number } \\
\text { of procedures }\end{array}$ & $\begin{array}{c}\text { Perforation } \\
\text { rate }(\%)\end{array}$ & $\begin{array}{c}\text { Mortality } \\
\text { rate }(\%)\end{array}$ & Comments \\
\hline \multicolumn{5}{|l|}{ Diagnostic colonoscopy } \\
\hline 1975, Rogers et al (1) & 25,298 & 0.22 & 0.008 & ASGE survey \\
\hline 1976, Smith (2) & 12,746 & 0.26 & 0.016 & Survey \\
\hline 1979, Fruhmorgen and Demling (3) & 28,527 & 0.14 & 0.020 & Multicentre survey article \\
\hline 1979, Stuart et al (4) & 442 & 1.30 & 0.200 & Retrospective single centre \\
\hline 1983, Macrae et al (5) & 3205 & 0.12 & 0 & Retrospective single centre \\
\hline 1984 , Gilbert et al (6) & 4713 & 0.17 & NA & ASGE survey \\
\hline 1990, Fruhmorgen and Pfahler (7) & 6609 & 0.05 & 0.015 & Retrospective single centre \\
\hline 1992, Reed et al (8) & 1000 & 0.12 & 0 & General surgeon survey \\
\hline 1992, Waye et al (9) & 1320 & 0 & 0 & $\begin{array}{l}\text { Ambulatory office procedures, } \\
\text { prospective single endoscopist }\end{array}$ \\
\hline 1996, Puchner et al (10) & 8989 & 0.08 & 0 & Retrospective single centre \\
\hline 1999, Eckardt et al (11) & 2500 & 0.04 & 0 & \\
\hline 2000, Anderson et al (12) & 6291 & 0.19 & 0 & Retrospective single centre \\
\hline 2001, Sieg et al (13) & 82,416 & 0.005 & 0.001 & $\begin{array}{l}\text { Prospective multicentre } \\
\text { outpatients only }\end{array}$ \\
\hline 2001, Dafnis et al (15) & 4677 & 0.11 & 0 & Retrospective multicentre \\
\hline 2001, Wexner et al (16) & 13,580 & 0.07 & NA & Prospective general surgeons \\
\hline Total & 202,313 & 0.09 & 0.006 & \\
\hline \multicolumn{5}{|l|}{ Therapeutic colonoscopy } \\
\hline 1975, Rogers et al (1) & 6214 & 0.29 & 0 & ASGE survey \\
\hline 1976, Smith (2) & 9238 & 0.52 & 0.01 & Polypectomy-associated \\
\hline 1979, Stuart et al (4) & 184 & 0 & 0 & Polypectomy-associated \\
\hline 1979, Fruhmorgen and Demling (3) & 7365 & 0.34 & 0.10 & Polypectomy-associated \\
\hline 1983, Macrae et al (5) & 1795 & 0.11 & 0 & Polypectomy-associated \\
\hline 1984, Gilbert et al (6) & 1901 & 0.11 & NA & Polypectomy-associated \\
\hline 1988, Nivatvongs (17) & 1576 & 0.06 & 0 & Polypectomy-associated \\
\hline 1990, Fruhmorgen anf Pfahler (7) & 2306 & 0.20 & 0 & Polypectomy-associated \\
\hline 1992, Waye et al (9) & 777 & 0.30 & 0 & Polypectomy-associated \\
\hline 1996, Puchner et al (10) & 1609 & 0.20 & 0.20 & Polypectomy-associated \\
\hline 1996, Kewenter and Brevinge (18) & 513 & 0.80 & 0 & Polypectomy-associated \\
\hline 2000, Anderson et al (12) & 4195 & 0.19 & 0.05 & Polypectomy-associated \\
\hline 2001, Sieg et al (13) & 14,249 & 0.06 & 0.007 & Polypectomy-associated \\
\hline 2001, Dafnis et al (15) & 1389 & 0.22 & 0 & $\begin{array}{l}\text { Two-thirds polypectomy- } \\
\text { associated }\end{array}$ \\
\hline Total & 53,311 & 0.24 & 0.03 & \\
\hline
\end{tabular}

ASGE American Society for Gastrointestinal Endoscopy; NA Not available

rates ranging from $0.005 \%$ to $0.20 \%(10-16)$ and therapeutic colonoscopic perforation rates ranging from 0.06 to $0.40 \%$ (11-15). Indeed, a recent diagnostic colonoscopic screening program for colon cancer in a healthy population involving over 3000 colonoscopies had a zero rate of perforation (19), implying the risk of colonoscopy-associated perforation may be lowest during screening of a healthy outpatient population.

Table 2 outlines the published reports of gastroscopyassociated perforation rates during the last 30 years. The rate of perforation with diagnostic gastroscopy has been described as lower than that of perforation associated with diagnostic colonoscopy. The rate of perforation at the time of diagnostic gastroscopy ranges from $0.0009 \%$ to $0.10 \%(7,13,20-25)$.
Again, similar to that seen with colonoscopy, the most recent studies report the lowest rates of perforation. Therapeutic gastroscopy carries an increased risk of perforation (range $0.3 \%$ to $6.4 \%$ ) and is almost always associated with dilation of malignant or benign esophageal strictures $(21,25)$. Interestingly, upper endoscopic perforations associated with bleeding ulcers was not described until recently, when a therapeutic endoscopic upper gastrointestinal bleeding clinical trial documented a perforation rate of $1.1 \%$ and $4.2 \%$ for endoscopic treatment and re-treatment, respectively (26).

Perforation rates provided to patients at the time of consent are frequently derived from the historical cohorts and survey data sets identified in Tables 1 and 2. There are currently no published Canadian endoscopic perforation data. The aim of 
TABLE 2

Published reports of gastroscopy-associated perforation rates during the last $\mathbf{3 0}$ years

\begin{tabular}{lcccc}
\hline $\begin{array}{l}\text { Author } \\
\text { year (ref) }\end{array}$ & $\begin{array}{c}\text { Number of } \\
\text { procedures }\end{array}$ & $\begin{array}{c}\text { Perforation } \\
\text { rate (\%) }\end{array}$ & $\begin{array}{c}\text { Mortality } \\
\text { rate (\%) }\end{array}$ & Comments \\
\hline Diagnostic gastroscopy & 23,500 & 0.11 & 0.004 & Survey \\
1972, Schiller et al (22) & 211,410 & 0.03 & 0.002 & ASGE survey \\
1974, Mandelstam et al (23) & 0.008 & NA & NA & Retrospective multicentre \\
1987, Miller (24) NA & NA & 0.01 & 0.008 & Prospective multicentre, outpatient \\
1990, Fruhmorgen and Pfahler (7) & 13,036 & 0.05 & 0.0009 & Dilation - bougienage \\
1995, Quine et al (25) & 110,469 & 0.0009 & 0.002 & Dilation - balloon \\
2001, Sieg et al (13) & 358,415 & 0.03 & & Esophageal stents \\
Total & & & 0.05 & Sclerotherapy \\
Therapeutic gastroscopy & NA & 0.5 & 0.50 & Hemostasis nonvariceal bleed \\
1992, Muhldorfer et al (21) & NA & 0.3 & 4.00 & Laser treatment \\
1992, Muhldorfer et al (21) & NA & 5.0 & 2.00 & Retrospective multicentre: \\
1992, Muhldorfer et al (21) & NA & 1.0 & 2.00 & dilation of benign stricture \\
1992, Muhldorfer et al (21) & NA & 1.0 & 0.50 & Dilation of neoplastic stricture \\
1992, Muhldorfer et al (21) & NA & 5.0 & & \\
1992, Muhldorfer et al (21) & 554 & 1.1 & 2.30 & \\
1995, Quine et al (25) & & 6.4 & 2.6 &
\end{tabular}

ASGE American Society for Gastrointestinal Endoscopy; NA Not available

this retrospective chart review was to determine recent Canadian gastroscopy- and colonoscopy-associated perforation rates at a Canadian tertiary care university teaching centre.

\section{METHODS}

The University of Alberta Hospital is a university teaching centre and a tertiary care referral hospital located in Edmonton, Alberta. It serves a catchment area of over 1.8 million people from central/northern Alberta, northwestern Saskatchewan, northern British Columbia and the Northwest Territories. Endoscopy at the University of Alberta Hospital is performed by three pediatric gastroenterologists, four hepatologists, six adult gastroenterologists and one general surgeon. Approximately 4500 gastroscopies and 2500 colonoscopies are performed annually. The hospital also serves as a Canadian training centre for between five to 10 gastroenterology subspecialty residents in any given year.

All inpatient and outpatient upper and lower endoscopies conducted at the University Hospital between January 1, 1998 and December 31, 2001 were evaluated. The University of Alberta Hospital uses the International Classification of Diseases (ICD) (27), on a prospective basis, to identify each procedure and diagnosis for every patient encounter. Previous reports have shown that over $90 \%$ of perforations resulting from endoscopy are diagnosed within two days of the procedure (12) Endoscopies with perforations, occurring within 14 days of the endoscopic procedure, were therefore isolated using the code descriptions listed in Table 3.

Identified records were retrieved and hand searched to confirm an endoscopic-associated perforation by consensus of two authors (TM and RF). Data were extracted to identify patient demographics, endoscopic indication and diagnosis, type of procedure, extent of insertion, preparation adequacy, trainee involvement, previous abdominal surgery, renal failure, surgical outcome and mortality. The type of procedure was recorded as either diagnostic or
TABLE 3

ICD code descriptions for endoscopies with perforations

\begin{tabular}{|c|c|}
\hline Endoscopic procedures & Diagnosis \\
\hline Anoscopy & Accidental cut/hemolysis during surgery \\
\hline Closed biopsy of large intestine & Accidental cut/hemolysis with scope \\
\hline Closed biopsy of rectum & Accidental puncture/laceration during \\
\hline Colonoscopy & procedure \\
\hline Dilation of anal sphincter & Hemorrhage of the gastrointestinal tract \\
\hline Dilation of esophagus & Other specific disorders rectum/anus \\
\hline Dilation of intestine & Perforation of intestine \\
\hline Dilation of pylorus & Peritonitis \\
\hline Dilation of rectum & Pneumomediastinum \\
\hline Esophagogastroduodenoscopy & Pneumonitis \\
\hline Esophagoscopy & Pneumoperitoneum \\
\hline Flexible sigmoidoscopy & Pneumothorax \\
\hline \multicolumn{2}{|l|}{ Gastroscopy } \\
\hline \multicolumn{2}{|l|}{ Other endoscopy small intestine } \\
\hline \multicolumn{2}{|l|}{ Percutaneous gastrostomy } \\
\hline \multicolumn{2}{|l|}{ Polypectomy } \\
\hline Rigid protosigmoidoscopy & \\
\hline
\end{tabular}

ICD International Classification of Diseases

therapeutic depending on the presence or absence of a therapeutic endoscopic maneuver. For gastroscopy, therapeutic maneuvers included dilation, stent placement, variceal and nonvariceal hemostatic procedures, and percutaneous endoscopic gastrostomy tube placement. For colonoscopy, therapeutic maneuvers included all therapeutic procedures identified for gastroscopy, plus polypectomy and decompression. The occurrence of mucosal biopsy was recorded as a diagnostic procedure. 
TABLE 4

Frequency of endoscopic perforations at the University of Alberta Hospital August 1998 to August 2001

\begin{tabular}{lllllll}
\hline & \multicolumn{3}{c}{ Gastroscopy } & & Colonoscopy \\
\hline & Diagnostic & Therapeutic & Total & Diagnostic & Therapeutic & Total \\
Number of procedures & 8062 & 5330 & 13,392 & 4470 & 2955 & 7425 \\
Number of perforation & 0 & 8 & 8 & 6 & 4 & 10 \\
Perforation rate & $0 \%$ & $0.15 \%$ & $0.06 \%$ & $0.13 \%$ & $0.14 \%$ & $0.13 \%$ \\
\hline
\end{tabular}

TABLE 5

Characteristics of patients with perforation following colonoscopy

\begin{tabular}{|c|c|c|c|c|c|c|c|c|}
\hline Patient & Sex & $\begin{array}{c}\begin{array}{c}\text { Age } \\
\text { (years) }\end{array} \\
\text { (years }\end{array}$ & $\begin{array}{c}\text { Procedure } \\
\text { type }\end{array}$ & Diagnosis & $\begin{array}{c}\text { Trainee } \\
\text { associated with } \\
\text { the procedure }\end{array}$ & $\begin{array}{l}\text { Previous } \\
\text { abdominal } \\
\text { surgery }\end{array}$ & $\begin{array}{l}\text { Renal } \\
\text { failure }\end{array}$ & $\begin{array}{c}\text { Adequate } \\
\text { preparation } \\
\text { documented }\end{array}$ \\
\hline 1 & $\mathrm{~F}$ & 74 & Diagnostic & Diverticuli & No & No & No & Not stated \\
\hline 2 & M & 64 & Diagnostic & Diverticuli & Yes & No & No & Yes \\
\hline 3 & M & 44 & Decompression & Ischemia, megacolon & No & No & No & Poor \\
\hline 4 & $\mathrm{~F}$ & 45 & Stricture dilation & Colonic stricture & No & No & No & Yes \\
\hline 5 & M & 58 & BICAP bleeding ulcer & Colonic ulcer & No & No & No & Poor \\
\hline 6 & $\mathrm{~F}$ & 70 & Diagnostic & Normal & No & Appendectomy & No & Yes \\
\hline 7 & $\mathrm{~F}$ & 75 & Diagnostic & Diverticuli & Yes & Cholecystectomy, hysterectomy & Hemodialysis & Not stated \\
\hline 8 & $\mathrm{~F}$ & 61 & Diagnostic & Severe colitis & Yes & No & Hemodialysis & Poor \\
\hline 9 & M & 70 & Diagnostic & Normal & Yes & No & No & Not stated \\
\hline 10 & $\mathrm{~F}$ & 42 & Polypectomy & Benign neoplasm & No & No & No & Not stated \\
\hline
\end{tabular}

BICAP Bipolar electrocoagulation; F Female; M Male

\section{RESULTS}

As shown in Table 4, a total of 21,217 endoscopies $(13,792$ gastroscopies [diagnostic 8062, therapeutic 5330] and 7425 colonoscopies [diagnostic 4470, therapeutic 2955]) were performed in the 36 months between August 1998 and August, 2001. Three hundred fifty-nine (167 inpatients and 192 outpatients) records were initially isolated for review based on the search criteria outlined above. Of these 359 cases, 358 were retrieved. One record of a colonoscopy was not reviewed because it was missing from the files. After hand searching all 358 retrieved cases, 18 of these records were found to have had an endoscopy-associated intestinal perforation.

\section{Colonoscopy}

Ten colonic perforations occurred during the 7425 colonoscopies, representing an overall colonoscopic perforation rate of $0.13 \%$ (incidence, $1.3 / 1000 ; 1 / 769$ procedures) (Table 3 ). Six colonoscopy-associated perforations occurred during 4470 diagnostic colonoscopies $(0.13 \%)$ (incidence, $1.3 / 1000 ; 1 / 769$ procedures), while four colonoscopy-associated perforations occurred during 2955 therapeutic colonoscopies (0.14\%) (incidence, 1.4/1000; $1 / 714$ procedures).

Table 5 demonstrates the characteristics of patients with colonoscopic perforation. The mean age was $60.3 \pm 6.2$ years with male:female ratio of 4:6. One patient died following the perforation $(0.013 \%)$ (incidence, $0.13 / 1000 ; 1 / 7692$ procedures). Of the 10 colonic perforations, four of 10 (40\%) were undergoing a therapeutic colonoscopic procedure (dilation of benign stricture, one patient, hemostasis, one patient, decompression, one patient, polypectomy, one patient). Of the six perforations in patients undergoing diagnostic colonoscopy, five of six $(85 \%)$ occurred in association with the following comorbid conditions: two occurred in the setting of diverticulosis, one patient was on hemodialysis, one patient had previous abdominal surgery, and one patient had a combination of diverticulosis, hemodialysis and history of abdominal surgery. Three of 10 (30\%) perforations (two therapeutic and one diagnostic colonoscopy) occurred because the colonoscopy was performed in a poorly prepped colon, although the state of the preparation was not reported in four of the perforations, perhaps underestimating the importance of adequate preparation in risk of perforation. Trainees were performing the colonoscopy at the time of perforation in four of $10(40 \%)$ of the cases (four diagnostic colonoscopies).

Management of patients following the identification of perforation varied considerably (Table 6). The diagnosis of perforation was made during the procedure in six of $10(60 \%)$ of the cases and on $\mathrm{x}$-ray, immediately following the procedure, in three of $10(30 \%)$ of the cases and at autopsy in one case $(10 \%)$. One patient was managed conservatively, two required primary surgical closure, four required surgical resection with anastomosis, two underwent surgical resection with ostomy formation and one died. The one death occurred in a critically ill patient in the intensive care unit, following a recent lung transplant. A colonoscopy was performed up to $30 \mathrm{~cm}$ and terminated due to very severe colitis. The patient then became bradycardic and arrested. The autopsy report confirmed an old walled off perforation in the area of the sigmoid, which likely worsened with insufflation of air during the procedure.

\section{Gastroscopy}

Eight upper gastrointestinal perforations occurred during the 13,392 gastroscopies, representing a perforation rate of $0.06 \%$ (incidence, $0.6 / 1000 ; 1.0 / 1667$ procedures) (Table 4). No 
gastroscopy-associated perforations occurred during 8062 diagnostic gastroscopies (0\%), while eight gastroscopy-associated perforations occurred during 5330 therapeutic gastroscopies $(0.15 \%)$ (incidence, $1.5 / 1000 ; 1 / 667$ procedures).

Table 7 demonstrates the characteristics of the patients with a perforation during gastroscopy. The mean age of the patients involved was $62.4 \pm 8.2$ years with a male:female ratio of 5:3. Of the eight gastroscopic perforations, all eight (100\%) involved a therapeutic procedure (esophageal dilations for malignant lesions, six patients, esophageal wall-stent placement, one patient, placement of percutaneous feeding tube, one patient). Three patients had a positive history of abdominal surgery. No patients had dialysis-dependent renal failure. Two of eight $(25 \%)$ perforations occurred in the setting of trainee involvement. There were no deaths reported following any gastroscopic perforations.

Like colonoscopy, the management of perforation following gastroscopy varied considerably (Table 8 ). The diagnosis of perforation was made during the procedure in three of the cases, and on $x$-ray, immediately following the procedure, in five of the cases (chest $x$-ray, three patients, gastrograffin swallow, two patients) Five patients were managed conservatively, one had an esophageal stent placed in the operating room to seal the perforation, and two underwent thoracotomies for esophageal repair. The surgically managed patients were discharged from hospital within 11 days of admission.

\section{DISCUSSION}

A review of previous publications suggests that the gastrointestinal perforation rate for diagnostic and therapeutic gastroscopy has remained relatively constant over the last several decades (Table 2), whereas the perforation rate for both diagnostic and therapeutic colonoscopy appears to have fallen, and then plateaued, during the last decade (Table 1). The reason for this change in colonoscopic complication rate likely relates to the more recent introduction of colonoscopy into the mainstream of gastrointestinal procedures and the advances that have since occurred in endoscopic equipment, techniques and operator training. Nevertheless, in these same reported cohorts (Tables 1 and 2) it is interesting to note that the average rate of perforation is approximately 85 -fold higher for therapeutic gastroscopy (approximately 2.6\%) than for diagnostic gastroscopy (approximately 0.03\%); and threefold higher for therapeutic colonoscopy (approximately $0.24 \%$ ) than for diagnostic colonoscopy (approximately $0.09 \%$ ); while mortality is
TABLE 6

Outcomes of patients with perforation following colonoscopy

\begin{tabular}{lllc}
\hline Patient & $\begin{array}{l}\text { Diagnosis } \\
\text { of perforation }\end{array}$ & Intervention & Death \\
\hline 1 & During procedure & Resection-primary anastomosis & No \\
2 & Free air on x-ray & Conservative managment & No \\
3 & Free air on x-ray & Resection-ostomy & No \\
4 & During procedure & Resection-ostomy & No \\
5 & During procedure & Resection-primary anastomosis & No \\
6 & During procedure & Primary closure of perforation & No \\
7 & During procedure & Resection-ostomy & No \\
8 & At autopsy & No & Yes \\
9 & During procedure & Resection-primary anastomosis & No \\
10 & Free air on x-ray & Primary closure of perforation & No \\
\hline
\end{tabular}

approximately 500-fold higher for therapeutic gastroscopy (approximately 1.0\%) than for diagnostic gastroscopy (approximately $0.002 \%)$; and 50-fold higher for therapeutic colonoscopy (approximately $0.03 \%$ ) than for diagnostic colonoscopy (approximately $0.006 \%$ ).

While over-reporting of perforations was avoided by the use of hand searching, it is possible that the lower rates of perforation observed in the current study may reflect under-reporting by the use of ICD codes to retrieve cases in a retrospective manner. However, the data obtained in this study are nonetheless superior to previous documentation using survey techniques.

Perforation at gastroscopy almost always occurred with dilation of a benign or a malignant esophageal stricture. In contrast, perforation at colonoscopy occurred with polypectomy, diverticulosis, poor preparation, previous abdominal surgery (and presumably adhesions) and dialysis-dependent renal failure. Except for dialysis, these associations with perforation have been previously described. Because the prevalence of these associated diagnoses is likely to be relatively high, it is not possible to associate these with risk factors for perforation.

The involvement of trainees as a significant factor in endoscopic perforation has not been previously confirmed (12). The current study had trainees involved in a minority of the cases; however, it was similarly impossible to determine the risk associated with trainees in that the total number of endoscopic cases the trainees were involved in was not

TABLE 7

Characteristics of patients with perforation following gastroscopy

\begin{tabular}{|c|c|c|c|c|c|c|c|}
\hline Patient & Sex & $\begin{array}{c}\text { Age } \\
\text { (years) }\end{array}$ & Procedure & Diagnosis & $\begin{array}{c}\text { Trainee } \\
\text { associated with } \\
\text { the procedure }\end{array}$ & $\begin{array}{c}\text { Previous abdominal } \\
\text { surgery }\end{array}$ & $\begin{array}{l}\text { Renal } \\
\text { failure }\end{array}$ \\
\hline 1 & $\mathrm{M}$ & 70 & Esophageal dilation & Esophageal carcinoma & Yes & No & No \\
\hline 2 & M & 57 & Feeding tube placement & Feeding concerns & No & No & No \\
\hline 3 & M & 79 & Esophageal wall stent placement & Esophageal carcinoma & No & Gastric-esophageal resection & No \\
\hline 4 & $\mathrm{~F}$ & 17 & Esophageal dilation & Esophageal benign stenosis & Yes & Jejunal interposition & No \\
\hline 5 & $\mathrm{~F}$ & 76 & Esophageal dilation & Gastric cardia carcinoma & No & $\begin{array}{l}\text { Gastric carcinoma resection, } \\
\text { esophageal-jejunal anastomosis }\end{array}$ & No \\
\hline 6 & $\mathrm{~F}$ & 86 & Esophageal dilation & Esophageal carcinoma & No & Unknown & No \\
\hline 7 & M & 47 & Esophageal dilation & Achalasia & No & No & No \\
\hline 8 & $M$ & 67 & Esophageal dilation & Esophageal carcinoma & No & No & No \\
\hline
\end{tabular}

F Female; M Male 
TABLE 8

Outcomes of patients with perforation following gastroscopy

\begin{tabular}{|c|c|c|c|}
\hline Patient & $\begin{array}{l}\text { Diagnosis } \\
\text { of perforation }\end{array}$ & Intervention & Death \\
\hline 1 & Gastrograffin & Conservative & No \\
\hline 2 & $\begin{array}{l}\text { Pneumomediastinum } \\
\text { on chest radiograph }\end{array}$ & $\begin{array}{l}\text { Conservative, repeat } \\
\text { gastroscopy normal } \\
\text { three days later }\end{array}$ & No \\
\hline 3 & $\begin{array}{l}\text { Pneumomediastinum } \\
\text { on chest radiograph }\end{array}$ & Conservative & No \\
\hline 4 & $\begin{array}{l}\text { Pneumothorax on } \\
\text { chest radiograph }\end{array}$ & $\begin{array}{l}\text { Thoracotomy - primary } \\
\text { esophageal repair and right } \\
\text { upper lobe wedge resection }\end{array}$ & No \\
\hline 5 & During procedure & $\begin{array}{l}\text { Conservative, repeat } \\
\text { dilation } 10 \text { days later }\end{array}$ & No \\
\hline 6 & During procedure & Conservative & No \\
\hline 7 & During procedure & $\begin{array}{l}\text { Thoracotomy - primary } \\
\text { esophageal repair }\end{array}$ & No \\
\hline 8 & Gastrograffin & $\begin{array}{l}\text { Esophageal stent placed in } \\
\text { operating room to seal } \\
\text { perforation }\end{array}$ & No \\
\hline
\end{tabular}

determined. Nevertheless, operator training and experience has been clearly shown to correlate with endoscopic adverse events, including perforation (28).

Reporting of endoscopic complication rates in patient consent forms is moving from the use of historical cohort data to site specific data, and more recently, it has been suggested that individual operator rates be recorded and reported (28). In this regard, the perforation rates described in the present report reflect those at the University of Alberta Hospital and may not be relevant to individual operators, or to sites where the risk mix is different than that at the University of Alberta Hospital.

\section{CONCLUSION}

In summary, endoscopic gastroscopy and colonoscopy procedures, especially those with therapeutic maneuvers, carry risks associated with perforation morbidity and mortality. Future proscpective studies are required to clearly determine the associated comorbid risk factors for endoscopic perforation.

ACKNOWLEDGEMENT: Crohn's and Colitis Foundation of Canada

\section{REFERENCES}

1. Rogers BHG, Silvis SE, Nebel OT, Sugawa C, Mandelstam P. Complications of flexible fiberoptic colonoscopy and polypectomy. Gastrointest Endosc 1975;22:73-7.

2. Smith LE. Fiberoptic colonoscopy: Complications of colonoscopy and polypectomy. Dis Colon Rectum 1976;19:407-12.

3. Fruhmorgen P, Demling L. Complications of diagnostic and therapeutic colonoscopy in the Federal Republic of Germany. Results of an inquiry. Endoscopy 1979;11:146-50.

4. Stuart M, Failes D, Killingback M, De Luca C. Fiberoptic colonoscopy: Indications, results and complications. Med J Aust $1979 ; 1: 596-8$
5. Macrae FA, Tan KG, Williams CB. Towards safer colonoscopy: A report on the complications of 5000 diagnostic or therapeutic colonoscopies. Gut 1983;24:376-83.

6. Gilbert DA, Hallstrom AP, Shaneyfelt SL, et al. The national ASGE colonoscopy survey - Complications of colonoscopy. Gastrointest Endosc 1984;30:156. (Abst)

7. Fruhmorgen P, Pfahler A. [Complications in 39,397 endoscopic studies - a 7 year prospective documentation on method and incidence]. Leber Magen Darm 1990;20:20-32.

8. Reed DN Jr, Collins JD, Wyatt WJ, et al. Can general surgeons perform colonoscopy safely? Am J Surg 1992;163:257-9.

9. Waye JD, Lewis BS, Yessayan S. Colonoscopy: A prospective report of complications. J Clin Gastroenterol 1992;15:347-51.

10. Puchner R, Allinger S, Doblhofer F, Wallner M, Knoflach P. [Complications of diagnostic and interventional colonoscopy]. Wien Klin Wochenschr 1996;108:142-6.

11. Eckardt VF, Kanzler G, Schmitt T, Eckardt AJ, Bernhard G. Complications and adverse effects of colonoscopy with selective sedation. Gastrointest Endosc 1999:49:560-5.

12. Anderson ML, Pasha TM, Leighton JA. Endoscopic perforation of the colon: Lessons from a 10-year study. Am J Gastroenterol 2000;95:3418-22.

13. Sieg A, Hachmoeller-Eisenbach U, Eisenbach T. Prospective evaluation of complications in outpatient GI endoscopy: A survey among German gastroenterologists. Gastrointest Endosc 2001;53:620-7.

14. Kavic SM, Basson MD. Complications of endoscopy. Am J Surg 2001:181:319-32.

15. Dafnis G, Ekbom A, Pahlman L, Blomqvist P. Complications of diagnostic and therapeutic colonoscopy within a defined population in Sweden. Gastrointest Endosc 2001;54:302-9.

16. Wexner SD, Garbus JE, Singh JJ, for the SAGES Colonoscopy Study Outcomes Group. A prospective analysis of 13,580 colonoscopies. Reevaluation of credentialing guidelines. Surg Endosc 2001;15:251-6.

17. Nivatvongs S. Complications in colonoscopic polypectomy: Lessons to learn from an experience with 1576 polyps. Am Surg 1988;54:61-3.

18. Kewenter J, Brevinge H. Endoscopic and surgical complications of work-up in screening for colorectal cancer. Dis Colon Rectum 1996;39:676-80.

19. Lieberman DA, Weiss DG, Bond JH, Ahnen DJ, Garewal H, Chejfec G. Use of colonoscopy to screen asymptomatic adults for colorectal cancer. Veterans Affairs Cooperative Study Group 380. N Engl J Med 2000;343:162-8.

20. Shahmir M, Schuman BM. Complications of fiberoptic endoscopy. Gastrointest Endosc 1980;26:86-91.

21. Muhldorfer AM, Kekos G, Hahn EG, Ell C. Complications of therapeutic gastrointestinal endoscopy. Endoscopy 1992;24:276-83.

22. Schiller KFCR, Cotton PB, Salmon PR. The hazards of digestive fibre-endoscopy: A survey of British experience. Gut 1972;13:1027.

23. Mandelstam P, Sugawa C, Silvis SE, Nebel OT, Rogers BHG. Complications associated with esophagogastroduodenoscopy and with esophageal dilation. Gastrointest Endosc 1976;23:16-9.

24. Miller G. [Complications of endoscopy of the upper gastrointestinal tract]. Leber Magen Darm 1987;17:299-304.

25. Quine MA, Bell GD, McCloy RF, Matthews HR. Prospective audit of perforation rates following upper gastrointestinal endoscopy in two regions of England. Br J Surg 1995;82:530-3.

26. Lau JYW, Sung JJY, Lam YH, et al. Endoscopic retreatment compared with surgery in patients with recurrent bleeding after initial endoscopic control of bleeding ulcers. N Engl J Med 1999;340:751-6.

27. International Classification of Diseases, 9th edn. World Health Organization, 1977.

28. Wexner SD, Litwin D, Cohen J, et al. Principles for privileging and credentialing in endocopsy and colonoscopy. Gastrointest Endosc 2002;55:145-8. 


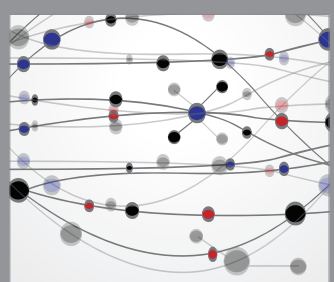

The Scientific World Journal
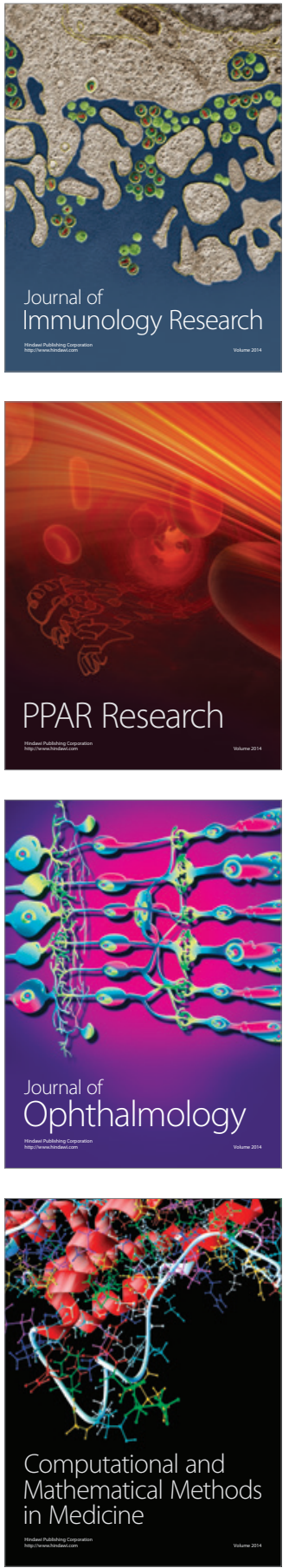

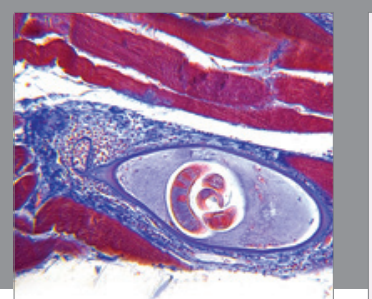

Gastroenterology Research and Practice

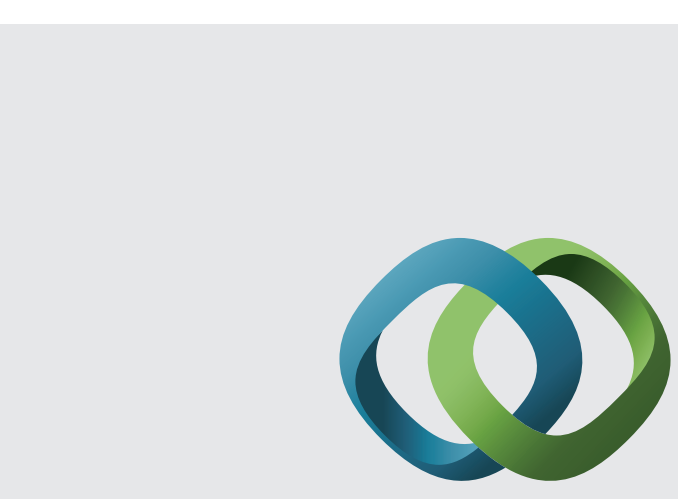

\section{Hindawi}

Submit your manuscripts at

http://www.hindawi.com
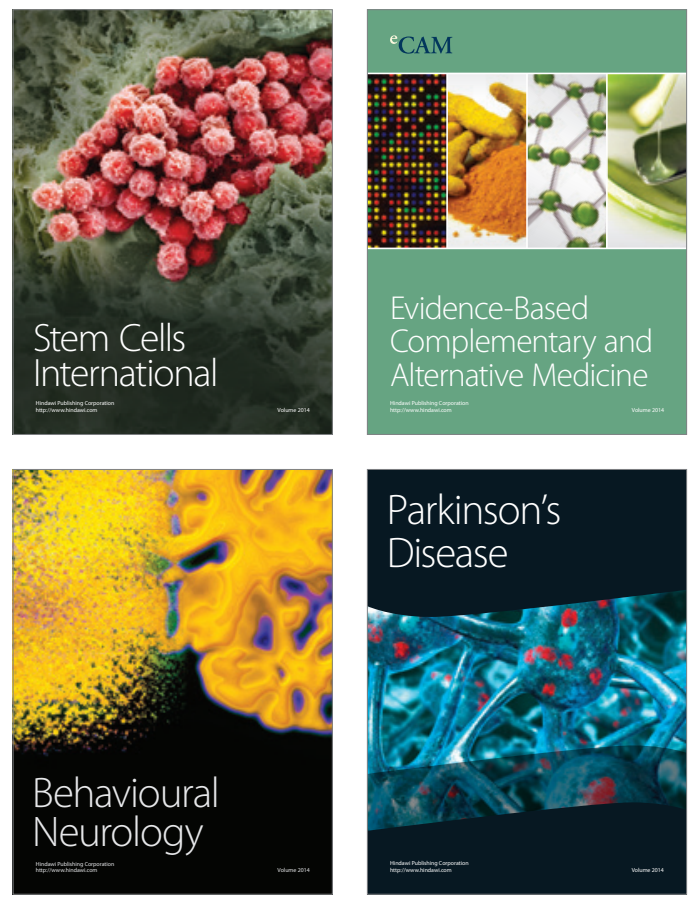
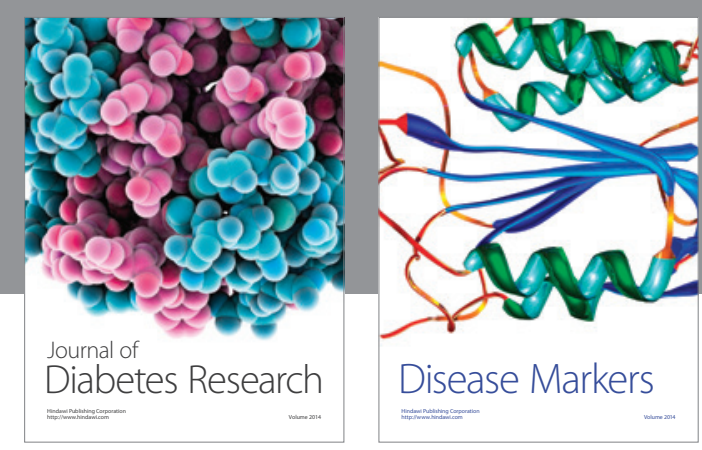

Disease Markers
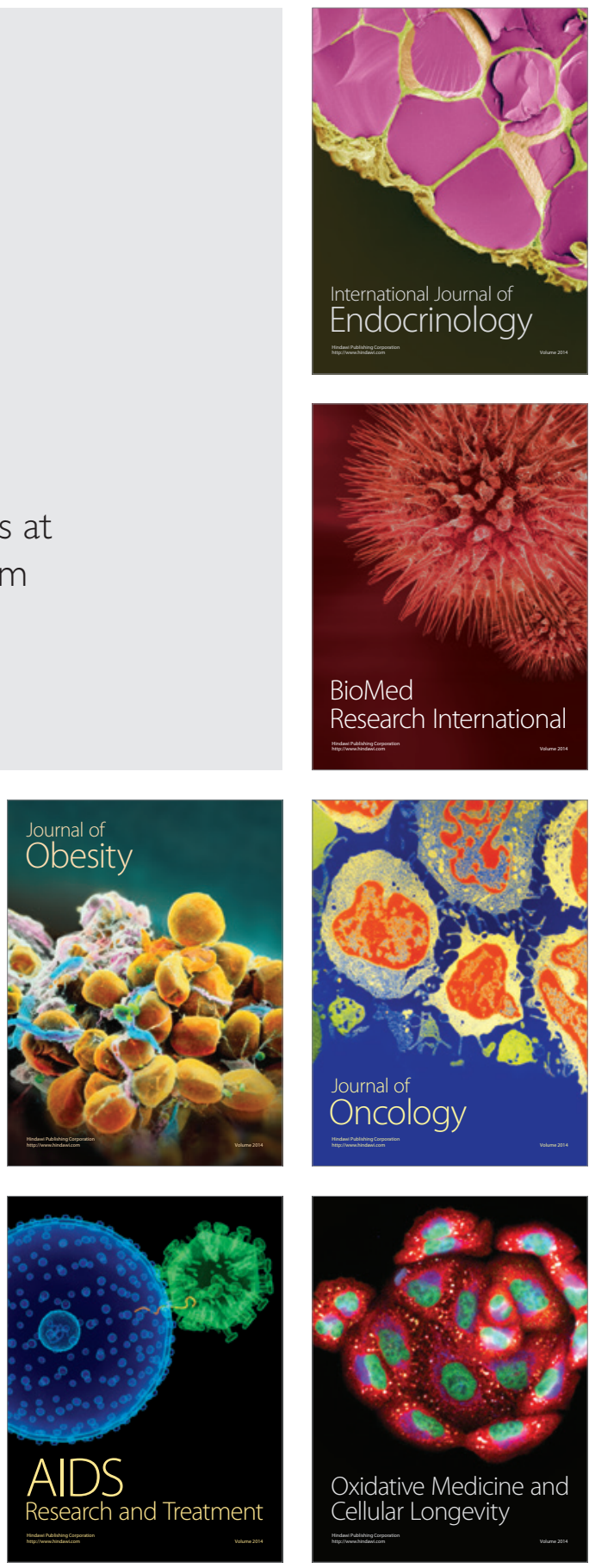